Review

\title{
Antisocial Personality Disorder in Bipolar Disorder: A Systematic Review
}

\author{
Elvira Anna Carbone ${ }^{+}\left(\mathbb{D}\right.$, Renato de Filippis ${ }^{+}\left(\mathbb{D}\right.$, Mariarita Caroleo $^{\dagger}$, Giuseppina Calabrò $(\mathbb{D}$, \\ Filippo Antonio Staltari, Laura Destefano, Raffaele Gaetano, Luca Steardo Jr. ${ }^{\dagger}$ and Pasquale De Fazio *
}

check for

updates

Citation: Carbone, E.A.; de Filippis, R.; Caroleo, M.; Calabrò, G.; Staltari, F.A.; Destefano, L.; Gaetano, R.; Steardo, L., Jr.; De Fazio, P. Antisocial Personality Disorder in Bipolar Disorder: A Systematic Review. Medicina 2021, 57, 183. https://doi. org/10.3390/medicina57020183

Academic Editor: Woojae Myung

Received: 8 January 2021

Accepted: 15 February 2021

Published: 20 February 2021

Publisher's Note: MDPI stays neutral with regard to jurisdictional claims in published maps and institutional affiliations.

Copyright: (c) 2021 by the authors. Licensee MDPI, Basel, Switzerland. This article is an open access article distributed under the terms and conditions of the Creative Commons Attribution (CC BY) license (https:/ / creativecommons.org/licenses/by/ $4.0 /)$.
Department of Health Sciences, University Magna Graecia of Catanzaro, Viale Europa, 88100 Catanzaro, Italy; elvira.carbone@libero.it (E.A.C.); defilippisrenato@gmail.com (R.d.F.); mariaritacaroleo.82@gmail.com (M.C.); giusy878@gmail.com (G.C.); filippostaltari89@gmail.com (F.A.S.); lds@laradestefano.com (L.D.); rafgae74@libero.it (R.G.); staerdo@unicz.it (L.S.J.)

* Correspondence: defazio@unicz.it; Tel./Fax: +39-0961-712369

+ These authors contributed equally to this work.

\begin{abstract}
Background and Objectives: Bipolar Disorder (BD) is a severe psychiatric disorder that worsens quality of life and functional impairment. Personality disorders (PDs), in particular Cluster B personality, have a high incidence among BD patients and is considered a poor prognostic factor. The study of this co-morbidity represents an important clinical and diagnostic challenge in psychiatry. Particularly, clinical overlap has been shown between antisocial personality disorder (ASPD) and BD that could worsen the course of both disorders. We aimed to detect the frequency of ASPD in bipolar patients with greater accuracy and the impact of ASPD on the clinical course of BD. Materials and Methods: A systematic literature search was conducted in PubMed, Embase, MEDLINE and the Cochrane Library through December 2020 without language or time restriction, according to PRISMA statement guidelines. Results: Initially, 3203 items were identified. After duplicates or irrelevant paper deletion, 17 studies met the inclusion criteria and were included in this review. ASPD was more frequent among BD patients, especially in BD type I. BD patients with ASPD as a comorbidity seemed to have early onset, higher number and more severe affective episodes, higher levels of aggressive and impulsive behaviors, suicidality and poor clinical outcome. ASPD symptoms in BD seem to be associated with a frequent comorbidity with addictive disorders (cocaine and alcohol) and criminal behaviors, probably due to a shared impulsivity core feature. Conclusions: Considering the shared symptoms such as impulsive and dangerous behaviors, in patients with only one disease, misdiagnosis is a common phenomenon due to the overlapping symptoms of ASPD and BD. It may be useful to recognize the co-occurrence of the disorders and better characterize the patient with ASPD and BD evaluating all dysfunctional aspects and their influence on core symptoms.
\end{abstract}

Keywords: bipolar disorder (BD); antisocial personality disorder (ASPD); comorbidity; substance abuse; outcome; systematic review

\section{Introduction}

Bipolar Disorder (BD) is a chronic affective disorder characterized by mood fluctuations with recurrent cycles of mania in BD I, or hypomania in BD II, and depression episodes [1,2], with a highly variable course among patients. The lifetime prevalence of $\mathrm{BD}$ is estimated to be around 2-3\% in the general population [3] and sub-threshold forms affect at least a further $2 \%$ [4]. BD is characterized by a worsening in quality of life [5] and functional impairment [6,7] and is frequently associated with other psychiatric comorbidities that could lead to a worse outcome [8-15]. It has been estimated that patients with BD are exposed to a second psychiatric disorder with longitudinal rates that can be higher than $50 \%$ and may reach even $70 \%$ [16]. The most common mental disorders that co-occur with $\mathrm{BD}$ are drug abuse $(33.5 \%)$, anxiety disorders $(31.8 \%)$, alcohol abuse $(18.3 \%)$, obsessivecompulsive disorder (OCD) (21\%), eating disorders (33\%), attention deficit hyperactivity 
disorder (ADHD) (25\%), and post-traumatic stress disorder (PTSD) (from 4 to $40 \%$ ) [17-23]. In addition, particularly high is the incidences of cluster B personality disorders in BD that are estimated at $41.2 \%$ even in the euthymic phase [24] and, represent a poor prognostic factor [25-28]. The study of this co-morbidity represents an important clinical and diagnostic challenge in psychiatry. Furthermore, Cluster B personality disorders have several common features with BD such as impulsivity, aggressive behavior, and mood instability, enough to induce some authors to consider them part of the bipolar spectrum [29]. Instead, features associated with Cluster B personality disorders may be a dimensional aspect of $\mathrm{BD}$, and when combined could result in greater complexity and severity of the disease [30,31]. Conversely, the presence of BD could worsen the course of a personality disorder [32]. Several studies have shown that the presence of cluster B personality in BD is associated with a higher number of episodes, substance abuse, illegal behavior, a higher rate of suicide risk, and a poor treatment adherence [32-34]. In this scenario, researchers have focused on the impact of personality disorder on $\mathrm{BD}$, investigating the common traits that mutually lead to a worse outcome [34]. Particularly, the clinical overlap has been shown between antisocial personality disorder (ASPD) and BD.

According to the DSM-5, the ASPD is described as the existence of constant and pervasive disposition to disregard and disrupt the rights of others. Other specific features include frequent violations of the law, mistreatment of others, deceitfulness, impulsivity, hostility, reckless disregard for the safety of self and others, and imprudent behaviors with lack of guilt, remorse, and empathy [35].

In fact, the prevalence of ASPD can be up to five times higher (4.1\%) [36] and appears to be more frequently identified in BD I than BD II [37]. ASPD and BD are both characterized by impulsive behaviors [38,39] and substance use disorder [40-42] that frequently lead to trouble with the law $[43,44]$ and suicidal behavior $[45,46]$. Studies suggested that impulsivity and the frequent abuse of drugs, especially alcohol, cannabis and amphetamines, is associated with sensation seeking and a lack of premeditation in ASPD and that when ASPD is co-morbid with BD it is associated with significant deficits in the ability to delay reward [47-49] and greater gray matter volume in the mesolimbic reward system [50]. These characteristics appear more severe when they are combined [50-52] and a more in depth characterization of ASPD comorbidity in patients with BD may help clinicians to distinguish both disorders and tailor the treatment. Thus, in an attempt to detect the frequency of ASPD in bipolar patients with greater accuracy and to better clarify the relationship between ASPD and $\mathrm{BD}$, we conducted a systematic review of the existing literature on the frequency of ASPD in BD I, BD II and cyclothymia, according to DSM or ICD diagnostic criteria, evaluating the impact on clinical characteristics and outcomes.

\section{Materials and Methods}

\subsection{Search Strategy}

We searched PubMed, Embase, MEDLINE, and the Cochrane Library for articles evaluating the comorbidity between BDs and ASPD published up to 1 December 2020. No language or time restriction were applied. We used the following keywords: "bipolar disorder OR affective disorder OR mood disorder OR bipolar disorders OR affective disorders OR mood disorders OR BD OR cyclothymia AND antisocial personality disorder OR ASPD OR AABS OR adult antisocial behavior syndrome OR antisocial behavioral syndrome" sorted by best match. Two researchers independently reviewed all the selected studies. Titles and abstracts of the identified papers were reviewed, and full texts considered relevant were recovered and revised. The reference lists of eligible studies were also hand-screened to search additional and useful studies to be included in the review. To improve the clarity of the review process, the PRISMA Statement criteria and recommendations were followed [53]. Figure 1 shows the research strategy. 


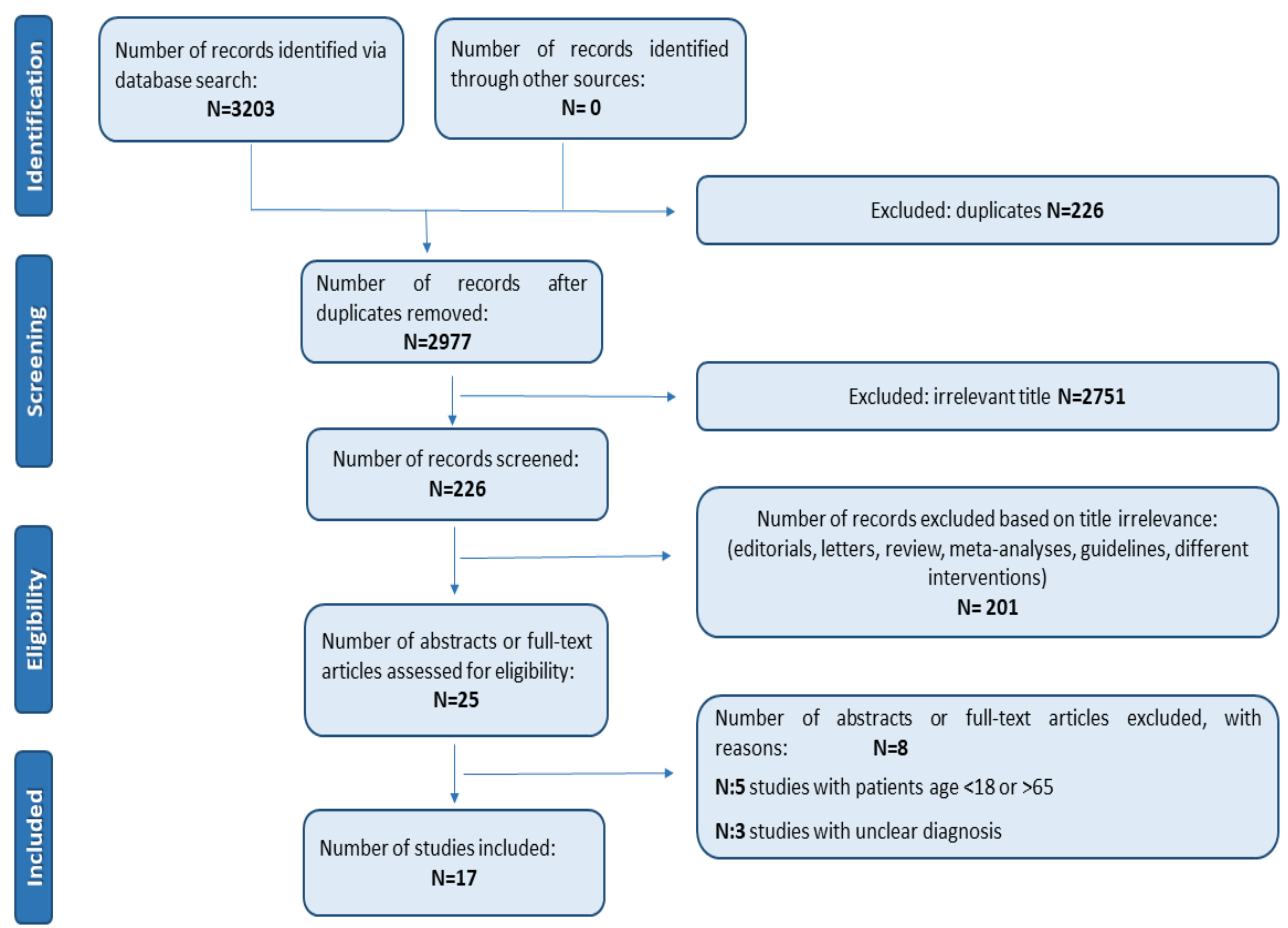

Figure 1. The PRISMA flow chart.

\subsection{Assessment of Study Quality}

Quality assessment was conducted using the Mixed Methods Appraisal Tool (MMAT) developed by Pluye et al. [54]. Piloting suggested that the MMAT was a reliable and efficient scoring system for appraising the quality of quantitative, qualitative, and mixedmethod studies. It provides a comprehensive manual with detailed instructions. The methodology was evaluated using five criteria: qualitative, randomized controlled, nonrandomized, observational descriptive, mixed methods [55]. For each study, a score of $20 \%$ was assigned if a criterion was met and $100 \%$ if all criteria were met, therefore the total score could range between 20 and $100 \%$. Studies were assigned quality scores by two reviewers (E.A.C. and R.d.F.); scores ranged from $80 \%$ to $100 \%$. The quality assessment was finally reviewed and agreed upon the whole review team.

\subsection{Selection Criteria}

Original articles were reviewed and reported. Relevant publications were identified, and the full texts of these articles were retrieved and reviewed. The reference lists of included studies were also screened in order to search useful literature. Studies with patients diagnosed with BD I, BD II or cyclothymia and ASPD according to DSM or ICD criteria, regardless of the phase of the disorder and/or pharmacological treatment, aged 18-65 (we excluded studies on adolescents because personality disorders are not diagnosed in childhood) were included in the review article. Studies with patients diagnosed with BD I, BD II or cyclothymia and ASPD, younger than 18 and older than 65, with neurological comorbidity, or traumatic brain injuries with loss of consciousness were excluded. We considered the studies concerning the lifetime prevalence of ASPD in BD.

\subsection{Data Collection and Extraction}

Two blind researchers (E.A.C. and R.d.F.) independently screened the titles and abstracts of the identified articles and performed data extraction. Articles that met the eligibility criteria were read in the full texts, and in cases of disagreement, such as selection discrepancies, a third researcher (M.C.) made the final decision. Article data included first author name, year of publication, sample size, diagnoses assessed in the study, scales of measurement and statistical data. 


\section{Results}

Initially, 3203 items were identified. After deletion of duplicates (226) by two reviewers (E.A.C., R.d.F.), 2977 papers remained. Exclusion of papers by title and abstract was made by two reviewers (E.A.C., R.d.F.) based on assessment of the inclusion and exclusion criteria. This process ended in the exclusion of 2751 papers. The title and abstracts screening was performed for the remaining 226 articles. In all, we excluded 201 articles because they were reviews, meta-analyses, letters to editors, editorials, guidelines, and case reports. Some of them had only a bipolar subgroup or other personality disorder as a comorbidity, or the diagnosis was not clear. Then, 8 manuscripts out of 25 papers were deleted because they did not fulfill the inclusion criteria: 5 papers included patients aged $<18$ or $>65$, and 3 papers had unclear diagnosis focusing on personality disorders and not specifying the diagnosis. The remaining 17 papers were deemed eligible and included in the present review (Table 1). A great heterogeneity was reported among studies included and wide variability in the sample number (from $N=21$ to $N=43,093$ ) [49,56]. ASPD prevalence in $\mathrm{BD}$ ranged between $4.8 \%$ and $63 \%$ [47,57] and was higher in BD I [37] than II [17,49,58] and, in particular, in BD patients with substance use disorder (SUD) comorbid [47-49] with combined cocaine and alcohol abuse was most frequent $[48,49,59]$. Patients with BD and ASPD in comorbidity showed early onset [58], a higher number of depressive and manic episodes [47], higher scores of depression [59] and psychosis [47], more aggressive [60], and impulsive $[47,61]$ traits and more suicide attempts [47]. The psychometric tools used to assess the psychopathology were the Alcohol Use Disorder and Associated Disabilities Interview Schedule (AUDADIS) [49,57], the 12-Item Short Form Survey (SF-12) [49,57], the Barratt Impulsiveness Scale (BIS-11) [47,58], the Temperament Evaluation of Memphis, Pisa, Paris and San Diego-auto-questionnaire version (TEMPS-A) [62], Hamilton Depression Rating Scale (HDRS) [60,63], Young mania rating scale (YMRS) [60,63], Brown-Goodwin Aggression Scale (BGA) [60], and the Schedule for Affective Disorders and Schizophrenia (SADS-C) $[47,63]$. 
Table 1. The main characteristics of the included studies.

\begin{tabular}{|c|c|c|c|c|c|}
\hline Authors, Years & Sample & Measurements & Results & Comments & MMAT \\
\hline Goldstein et al., 2017 [57] & $N=36,309$ & AUDADIS-5; SF-12 & $\begin{array}{c}\text { Lifetime prevalence: ASPD + BD1: } 11.8 \% \\
\text { AABS + BD1: } 4.8 \% \\
\text { OR (C.I.) lifetime of BD } 1 \text { comorbidity: } \\
\text { ASPD } 2.9(1.93-4.28) \text { AABS } 1.9(1.43-2.50)\end{array}$ & $\begin{array}{l}\text { Comorbidity is higher in the } \\
\text { ASPD than in the AABS. Patients } \\
\text { with ASPD has a } 3 \text { times fold risk } \\
\text { of BD, while it is } 2 \text { times greater } \\
\text { if it has AABS }\end{array}$ & $* * * * *$ \\
\hline Lev-Ran et al., 2013 [49] & $N=43,093$ & AUDADIS-IV; SF-12 & $\begin{array}{c}\text { 12-month prevalence: BD + CUD + ASPD: } \\
49.9 \% \text { BD + No CUD + ASPD: } 18.2 \% \\
\text { OR (C.I.): } \\
2.75 \text { (1.63-4.64) }\end{array}$ & $\begin{array}{c}\text { The bipolar patient with CUD is } \\
\text { almost } 3 \text { times more likely to } \\
\text { have ASPD than the bipolar } \\
\text { patient without CUD }\end{array}$ & $* * * * *$ \\
\hline Swann et al., 2013 [58] & $\begin{array}{c}N=55 \\
4 \text { BD II } \\
51 \text { BD I } \\
14=\text { no Axis II disorder (8 men } \\
\text { and } 6 \text { women) } \\
35 \text { ASPD }(20 \\
\text { men and } 15 \text { women) } \\
23 \text { Borderline } 8 \\
\text { men and } 15 \text { women } \\
17 \text { (7 men and } \\
10 \text { women) both disorders }\end{array}$ & $\begin{array}{c}\text { Diagnosis was made by } \\
\text { Structured Clinical Interview } \\
\text { for DSM-IV } \\
\text { SCID-II } \\
\text { Schedule for Affective } \\
\text { Disorders and Schizophrenia } \\
\text { (SADS-C) } \\
\text { Barratt Impulsiveness Scale } \\
\text { (BIS-11) }\end{array}$ & $\begin{array}{c}\text { Prevalence: } \\
\text { 35 ASPD of 55 BD:63\% } \\
17 \text { ASPD + Borderline of 55: } 30.9 \% . \\
\text { Number of episodes: ASPD symptoms } \\
\text { predicted a history of many depressive } \\
\text { and manic episodes (but not either type } \\
\text { alone) and a early onset. } \\
\text { BIS-11 score: } \\
\text { Total, motor, and attentional BIS-11 scores } \\
\text { were predicted significantly by borderline } \\
\text { symptom scores with no significant } \\
\text { contribution from ASPD scores. Suicide } \\
\text { attempts: Impulsivity in ASPD + BD did } \\
\text { not contribute significantly to history of } \\
\text { suicide attempt } \\
\text { SUD Comorbidity: } \\
\text { ASPD symptoms predicted history of } \\
\text { alcohol, other substance-abuse disorder, } \\
\text { and smoking. }\end{array}$ & $\begin{array}{l}\text { ASPD symptoms were more } \\
\text { strongly related to course of } \\
\text { illness (i.e., early age at onset, } \\
\text { frequency of affective episodes, } \\
\text { suicide attempts and } \\
\text { substance-related disorders) but } \\
\text { not to impulsivity. }\end{array}$ & $* * * *$ \\
\hline Mueser et al., 2012 [59] & $N=103$ & $\begin{array}{c}\text { SCID-II; Time-line } \\
\text { Follow-back Calendar; AUS; } \\
\text { DUS; SATS; BPRS; GAS; } \\
\text { Knowledge Test; SPSI; FAS; } \\
\text { SF-12; FEIS }\end{array}$ & $\begin{array}{c}\text { Prevalence: } \\
21 \text { ASPD of which } 11 \text { BD: 52\% }\end{array}$ & $\begin{array}{l}\text { Over half of the antisocial } \\
\text { patients are also bipolar }\end{array}$ & $* * * * *$ \\
\hline
\end{tabular}


Table 1. Cont.

\begin{tabular}{|c|c|c|c|c|c|}
\hline Authors, Years & Sample & Measurements & Results & Comments & MMAT \\
\hline Perugi et al., 2012 [62] & $N=106$ & $\begin{array}{l}\text { CGI-BP; TEMPS-A; SAS; } \\
\text { IPSM; SIMD-R }\end{array}$ & $\begin{array}{c}\text { Prevalence: } \\
\text { BD I + ASPD: } 8.49 \%\end{array}$ & $\begin{array}{l}\text { The authors evaluated the impact } \\
\text { of the affective phase of BD1 on } \\
\text { axis II diagnosis, concluding that } \\
\text { ASPD is more represented among } \\
\text { hyperthymic than cyclothymic, } \\
\text { depressive or euthymic patients } \\
\text { and affective temperaments may } \\
\text { influence both clinical features } \\
\text { and axis I and II comorbidities. }\end{array}$ & $* * * *$ \\
\hline Swann et al., 2011 [61] & $\begin{array}{c}N=133 \\
46 \mathrm{HC} \\
21 \mathrm{BD} \text { without personality } \\
\text { disorders } \\
\text { 50ASPD without BD } \\
\text { 16BD + ASPD }\end{array}$ & $\begin{array}{c}\text { Immediate Memory Task } \\
\text { (IMT) } \\
\text { Two Choice Impulsivity } \\
\text { Paradigm (TCIP) }\end{array}$ & $\begin{array}{c}\text { Prevalence: } \\
\text { 16 ASPD of 37 BD: } 43.24 \% \\
\text { Impulsivity: } \\
\text { Impulsivity was increased in the } \\
\text { combined disorders compared to both } \\
\text { disorders alone. } \\
\text { Outcome: } \\
\text { In combined ASPD and BD increased } \\
\text { reaction speed, impulsive response bias, } \\
\text { and reward- delay impulsivity occurred. It } \\
\text { was independent of substance-use } \\
\text { disorder history. }\end{array}$ & $\begin{array}{l}\text { The combination of ASPD and } \\
\text { BD was associated with more } \\
\text { impulsive TCIP performance } \\
\text { compared to HC. Compensatory } \\
\text { mechanisms for impulsivity in } \\
\text { uncomplicated ASPD or BD } \\
\text { appear to be compromised or lost } \\
\text { when the disorders are in } \\
\text { comorbidity. }\end{array}$ & $* * * *$ \\
\hline Goldstein et al., 2010 [17] & $N=2442$ & AUDADIS-IV & $\begin{array}{c}\text { Prevalence: } \\
\text { BD1 + ASPD: } 45.1 \%(p<0.0001) \text { BD2 + } \\
\text { ASPD: } 8.2 \%(p<0.0122) \text { BD1 + AABS: } \\
32.4 \% \\
\text { BD2 + AABS: } 5.8 \%\end{array}$ & $\begin{array}{l}\text { In subjects with PTSD and ASPD, } \\
\text { comorbidity with DB } 1 \text { is the } \\
\text { strongest evidence, that with DB } \\
\text { 2, although lower, however, is } \\
\text { statistically significant. }\end{array}$ & $* * * * *$ \\
\hline Swann et al., 2010 [47] & $\begin{array}{c}N=197 \\
78 \mathrm{HC} \\
34 \mathrm{ASPD} \\
61 \mathrm{BD} \\
24 \mathrm{BD}+\mathrm{ASPD}\end{array}$ & SCID-II; SADS-C; BIS-11 & $\begin{array}{c}\text { Prevalence: } \\
\text { 12.4\% of total sampleSADS-C score: } \\
\text { Higher scores of depression and psychosis } \\
\text { BIS-11 score: } \\
\text { higher subscale and total score } \\
\text { Suicide attempts: } \\
\text { BD + ASPD: } 65.4 \% \\
\text { BD: } 34.9 \% \text { SUD Comorbidity: } \\
\text { BD + ASPD: } 91.3 \% \\
\text { BD: } 66.7 \% \text { Number of episodes: } \\
\text { Higher number of manic and depressive } \\
\text { episodes }\end{array}$ & $\begin{array}{l}\text { Comorbidity is associated with a } \\
\text { greater tendency to depression } \\
\text { and psychosis, an increased } \\
\text { number of depressive and manic } \\
\text { episodes, greater impulsivity, } \\
\text { greater risk of SUD and suicide. }\end{array}$ & $* * * *$ \\
\hline
\end{tabular}


Table 1. Cont.

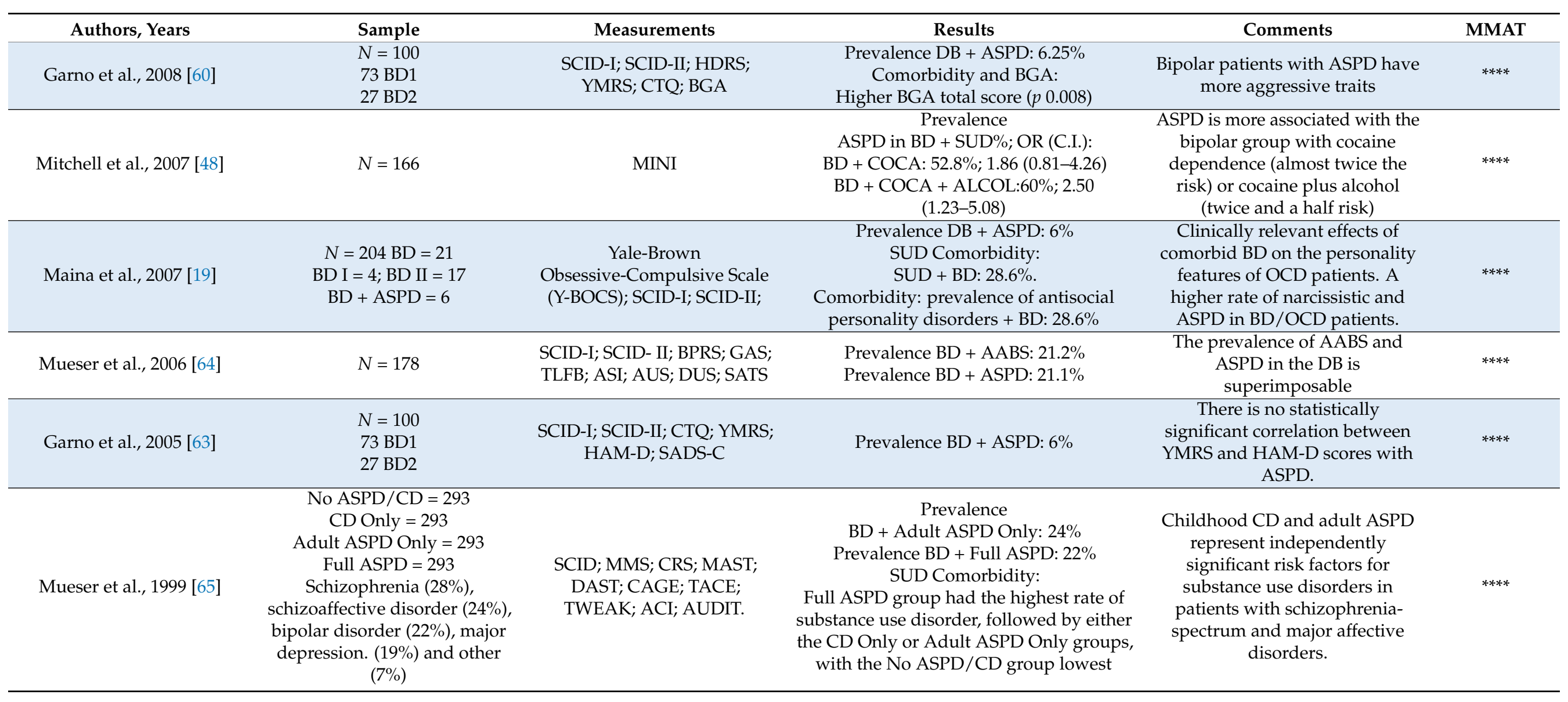


Table 1. Cont.

\begin{tabular}{|c|c|c|c|c|c|}
\hline Authors, Years & Sample & Measurements & Results & Comments & MMAT \\
\hline Jackson \& Pica, 1993 [66] & $\begin{array}{c}112 \text { psychiatric inpatients } \\
11 \text { antisocial personality } \\
\text { disorder, } 65 \text { had other forms of } \\
\text { personality disorders, } 36 \text { no } \\
\text { personality disorder. } \\
35 \text { recent-onset schizophrenic } \\
\text { patients ( } 27 \text { men, } 6 \text { women), } 26 \\
\text { recent-onset bipolar disorder } \\
\text { patients (14 men, } 12 \text { women), } \\
30 \text { unipolar affective disorder } \\
\text { patients (14 men, } 16 \text { women), } \\
\text { and } 21 \text { (11 men, } 10 \text { women) } \\
\text { with mixed disorders (e.g., } \\
\text { anorexia nervosa, substance } \\
\text { abuse, somatoform disorders) }\end{array}$ & $\begin{array}{c}\text { SCID, Royal Park } \\
\text { Multidiagnostic Instrument } \\
\text { for Psychoses, SAPS, SANS, } \\
\text { BDI BRMS }\end{array}$ & $\begin{array}{c}\text { Prevalence: } \\
4 \text { patients of } 11 \text { antisocial are affected by } \\
\text { BD. }\end{array}$ & $\begin{array}{l}\text { Patients with ASPD were } \\
\text { younger, with lower level of } \\
\text { education and higher levels of } \\
\text { many dysfunctional behaviors, as } \\
\text { delinquency, sexual intercourse, } \\
\text { drink/drugs abuse, thefts, } \\
\text { vandalism, inconsistent work, } \\
\text { irritability/aggressive, } \\
\text { impulsivity, recklessness, } \\
\text { continual antisocial behavior } \\
\text { than patients with other or none } \\
\text { PDs. }\end{array}$ & $* * * *$ \\
\hline Turley et al., 1992 [56] & $\begin{array}{l}21 \text { recent onset BD } \\
\text { (12 man and } 9 \text { women) }\end{array}$ & $\begin{array}{l}\text { MCMI-II); SIDP; BDI; SAPS; } \\
\text { BRMS; SCID-P }\end{array}$ & $\begin{array}{l}\text { The overall ratio of personality disorders } \\
\text { identified was virtually equivalent for the } \\
\text { MCMI- I1 and the SIDP. However, the } \\
\text { MCMI-I1 was far more likely to make } \\
\text { multiple diagnoses than the SIDP. The } \\
\text { MCMI-I1 identified a total of } 52 \\
\text { personality disorders compared with } \\
30 \text { for the SIDP. }\end{array}$ & $\begin{array}{l}\text { Narcissistic and Antisocial } \\
\text { personality disorders were the } \\
\text { most prevalent disorders in this } \\
\text { sample of Bipolar disordered } \\
\text { patients, followed by Histrionic } \\
\text { and Passive-Aggressive disorders }\end{array}$ & $* * * *$ \\
\hline Pica et al., 1990 [67] & $\begin{array}{c}N=26 \\
16 \text { BD } \\
10 \text { Schizoaffective Disorder }\end{array}$ & $\begin{array}{l}\text { SIDP; SCID-P; RPMIP; BDI; } \\
\text { BRMS; SAPS; SANS }\end{array}$ & $\begin{array}{c}\text { Prevalence } \\
\text { BD + ASPD: } 15.39 \%\end{array}$ & $\begin{array}{l}\text { Patients with BD showed a high } \\
\text { frequency of PDs. }\end{array}$ & $* * * *$ \\
\hline
\end{tabular}

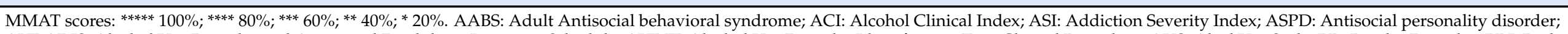

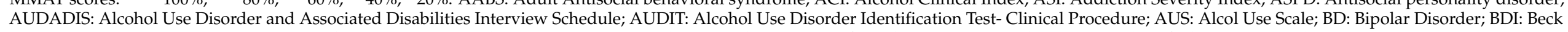

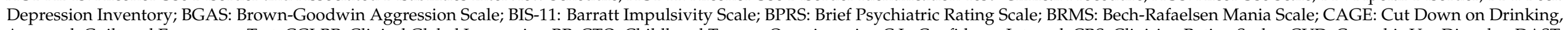

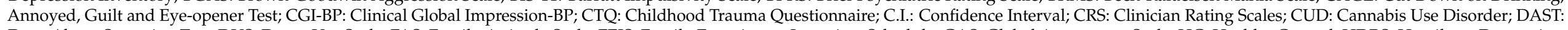

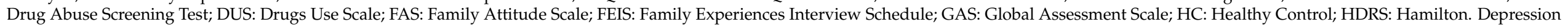

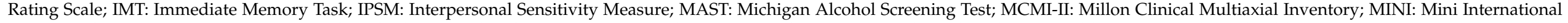

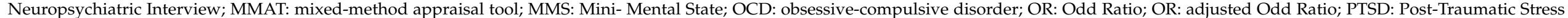

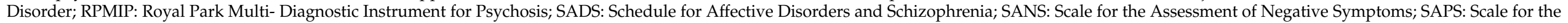

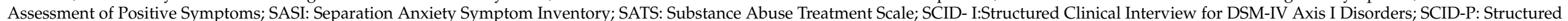

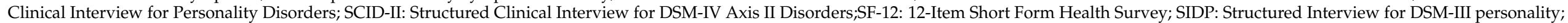

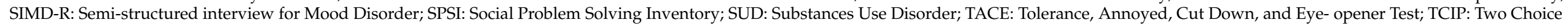

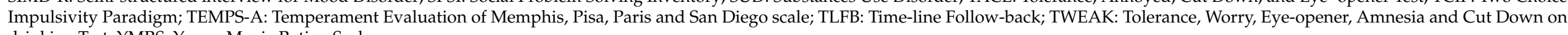
drinking Test; YMRS: Young Mania Rating Scale. 


\section{Discussion}

To the authors' knowledge, this is the first systematic review that assessed the association and the impact of ASPD and BD. It is worth mentioning how scarce the studies are that evaluate this association despite the high clinical relevance. The literature demonstrated a high incidence of Axis II personality disorders in patients with DB [24,68] and the more frequent were Cluster B personality disorders $[19,25-27,69]$ followed by $C$ and A $[17,47,58,67]$. Antisocial personality disorders [59] together with narcissistic $[19,70]$ and histrionic personality disorder were diagnosed most frequently in BD patients, even in recent-onset BD patients [56]. Pica et al., found that $62 \%$ of BD patients had PDs and ASPD was present in 15-39\% [67]. Moreover, as can be seen from the studies, a prevalence of 30\% ASPD in BD was reported, with a superior incidence in BD I than in BD II. A greater occurrence of antisocial behavior [29] and greater impulsivity during episodes, especially during mania has been demonstrated [52]. The clinical severity due to the co-occurrence of the two disorders and therefore the greater demand for access to clinical services could explain this higher prevalence. This great variability found in this review $(4.8 \%$ to $63 \%[47,57])$ may be due to the variable sample size and population selected of included studies (from $N=21$ to $N=43,093)[49,56]$, the retrospective nature of the included studies, the methodological differences (e.g., instruments used, phase of the disorder at the time collection) that may negatively affect the ability to discriminate between ASPD and BD diagnoses due to the high prevalence of $\mathrm{BD}$ in the general population and the lack of a precise tool for ASPD diagnostic assessment.

As expected, ASPD in comorbidity with BD is associated with a more severe course of illness and poor responsiveness and adherence to treatment [71,72]. ASPD in BD patients was associated with a poor outcome after a manic episode [73], a higher rate of suicide attempts [63,74], and a worse course of illness [75], with greater service admission [76]. Moreover, the greatest number of depressive events associated with the comorbidity with PDs results in a reduction in the quality of life, and since this is the most frequent suicide attempt during depressive phases, this may explain why patients with comorbidity also have a greater tendency to attempt suicide [77]. Patients with BD and ASPD showed an earlier onset of affective symptomatology [58], higher psychopathological burden [58,63], and a higher number of affective episodes [47]. An earlier age at onset of the antisocial behavior has been also described [32] that often persists in adulthood [78]. Notably, earlier onset is associated with a poorer prognosis in both disorders [79,80], probably due not only to the genetic contribution [81,82] but also to the environmental influences (e.g., child maltreatment, abuse, violence, harsh and inconsistent parental discipline, and lower quality caregiving) [83,84]. These patients have been also found to have a higher score of aggressivity measured with the BGA [60], higher impulsivity measured by the BIS-11 [47,58,61], and more suicide attempts [47]. Manic episodes can more easily lead to criminal penalties, illegal conduct therefore indirectly impacts treatment adherence [85]. Low treatment rates were found in patients with ASPD [57] and reflect affected individuals lack of insight into the seriousness of their problem and consequently lack of effective interventions. Even if BD demonstrated a higher rate of treatment compared to patients affected by ASPD, the co-occurrence of two disorders, often in younger patients, may interfere with treatment, as well as the ability to adhere to the treatment, with consequent poor outcome [59].

ASPD symptoms were associated with a history of alcohol or other SUDs as well as smoking. Substance abuse before 15 years is strongly related to ASPD $[64,86]$ and ASPD symptoms were related to age at BD onset independently of gender [58]. Lev-Ran and colleagues estimated the 12-month prevalence of BD, SUD (cannabis), and ASPD as $49.9 \%$, compared to $18.2 \%$ of patients with BD and without SUD [49]. Studies described cocaine and alcohol combined abuse as most frequent in BD and ASPD [48,49]. A more severe course of illness was found in comorbid SUD in bipolar patients, including an earlier onset, more rapid progression to dependence, and greater social, legal, and physical use consequences [64]. The frequent comorbidity with addictive disorders, suicidality, 
and criminal behaviors described, could be probably due to a shared impulsivity core feature [52]. A high level of impulsivity has been shown in patients affected by BD in comorbidity with ASPD measured by the Immediate Memory Task (IMT) and Two Choice Impulsivity Paradigm (TCIP). Moreover, faster Immediate Memory Task (IMT) reaction times in BD combined with SUD compared to BD alone have been reported [52]. The results suggest that loss of compensatory mechanisms may lead to more severe impulsivity in the combined disorders [52]. Another important aspect is the influence of temperament, which, in BD patients, can give rise to the predisposition to develop ASPD. Perugi et al. evaluated the influence of the affective temperament and psychopathological traits in a sample of patients with BD I and ASPD and found a higher incidence of hyperthymic temperaments in this population $(8.49 \%$ ) [62], suggesting that affective temperament influences clinical features of BD when in comorbidity with Axis II disorders [62].

Thus, comorbidity with ASPD seems to impact not only the onset but also the cyclical nature of $\mathrm{BD}$, increasing the number of episodes, psychopathological scores, suicide attempts, and poor adherence to treatment (Figures 2 and 3). Considering the shared symptoms such as impulsive and dangerous behaviors (i.e., substance abuse, driving recklessly, inappropriate sexual behavior), in patients with only one disease, misdiagnosis is a common phenomenon due to the overlapping symptoms of ASPD and BD. It may be useful to recognize the co-occurrence of the disorders and disentangle whether the two disorders are independent or interdependent conditions.

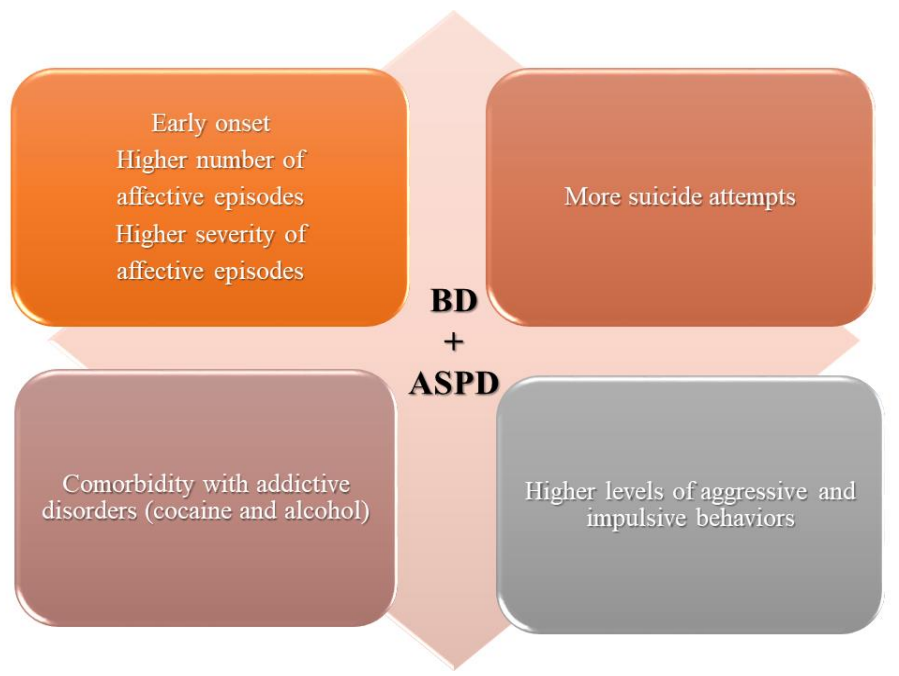

Figure 2. Main results.

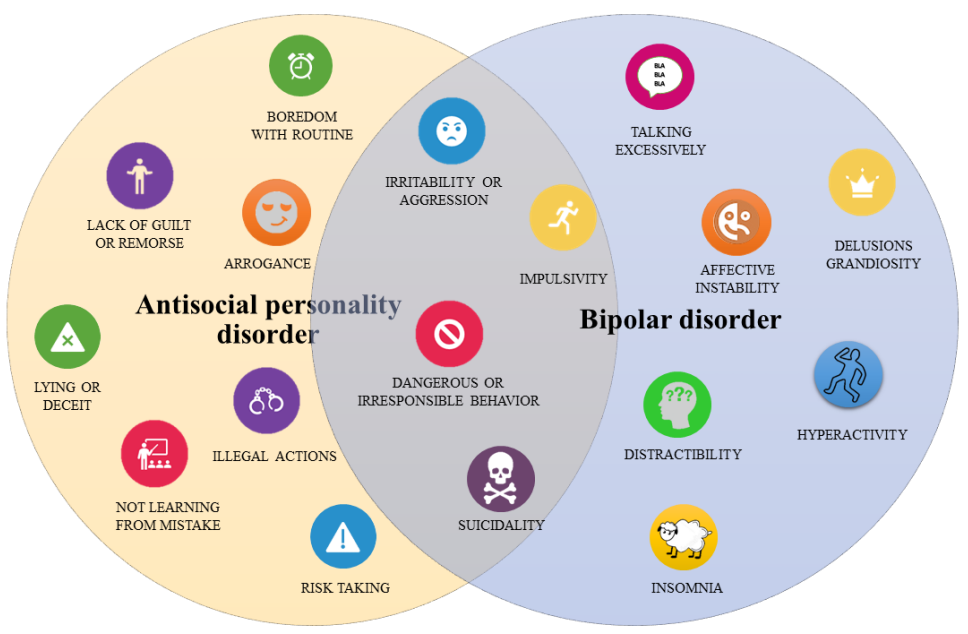

Figure 3. Overlapping symptoms between ASPD and BD. 


\section{Limits and Future Directions}

This review presents gray areas that deserve to be further explored. Potential limitations to consider include: (1) studies selected often determine the course of illness retrospectively. Moreover, many studies enrolled patients regardless of the phase of the illness. The results of the diagnostic assessments may be affected by the state of illness, thus reducing the quality of the included studies; (2) great heterogeneity and wide variability in the sample number and population selected was reported among studies making it difficult to correctly define the prevalence; (3) mechanisms underlying ASPD or AABS characteristics may be different in individuals with BD compared to those without BD; (4) additional comorbidities with further personality disorders were not systematically evaluated by the included studies. Although this does not affect the epidemiological results, it could limit their psychopathological interpretation. It should be necessary to better characterize comorbidity, evaluating all dysfunctional aspects of diseases and how they could influence core symptoms and comorbidity. It may be necessary to evaluate psychopathy within BD, as it is plausible that comorbid antisocial traits are different from the psycho-antisocial traits. It should also be necessary to evaluate whether patient profiles with comorbidity could benefit from different treatments. Psychopathy has not been investigated because of the difficulty of its classification according to DSM in relation to ASPD.

\section{Conclusions}

ASPD was estimated as more frequent among BD patients, especially in BD type I. BD patients with ASPD as a comorbidity seemed to have early onset, a higher number of manic and depressive episodes, more severe affective episodes, higher levels of aggressive and impulsive behaviors. Comorbidity is associated with a worse prognosis, increased frequency of relapse, poor clinical outcome, higher frequency of dangerous behaviors, a higher rate of suicide attempts and poorer treatment adherence. Furthermore, ASPD symptoms in BD patients seem to be also associated with frequent comorbidity with addictive disorders (alcohol or cocaine abuse disorder), suicidality, and criminal behaviors, probably due to a shared impulsivity core feature. Therefore, we suggest better characterization of the patient with BD and ASPD. Based on the literature data, considering the comorbidity between BD and ASPD and common elements between ASPD and psychopathy, it would be desirable to carry out clinical trials that also investigate in-depth the comorbidity among the three conditions together. Indeed, the presence of psychopathy in patients with BD and ASPD may have important consequences in clinical, prognostic, and therapeutic terms.

Author Contributions: Idealization, P.D.F.; literature search and data analysis, E.A.C., R.d.F. and M.C.; writing—original draft preparation, E.A.C., R.d.F., M.C. and L.S.J.; writing-review and editing, E.A.C., R.d.F., G.C., F.A.S., L.D., R.G., L.S.J. and P.D.F. All authors have read and agreed to the published version of the manuscript.

Funding: This research received no external funding.

Institutional Review Board Statement: Not applicable.

Informed Consent Statement: Not applicable.

Data Availability Statement: Data available on request.

Conflicts of Interest: The authors declare no conflict of interest.

\section{References}

1. Grande, I.; Berk, M.; Birmaher, B.; Vieta, E. Bipolar disorder. Lancet 2016, 387, 1561-1572. [CrossRef]

2. Jann, M.W. Diagnosis and treatment of bipolar disorders in adults: A review of the evidence on pharmacologic treatments. Am. Health Drug Benefits 2014, 7, 489-499. [PubMed]

3. Merikangas, K.R.; Jin, R.; He, J.-P.; Kessler, R.C.; Lee, S.; Sampson, N.A.; Viana, M.C.; Andrade, L.H.; Hu, C.; Karam, E.G.; et al. Prevalence and Correlates of Bipolar Spectrum Disorder in the World Mental Health Survey Initiative. Arch. Gen. Psychiatry 2011, 68, 241. [CrossRef] [PubMed] 
4. Koirala, P.; Hu, B.; Altinay, M.; Li, M.; DiVita, A.L.; Bryant, K.A.; Karne, H.S.; Fiedorowicz, J.G.; Anand, A. Sub-threshold bipolar disorder in medication-free young subjects with major depression: Clinical characteristics and antidepressant treatment response. J. Psychiatr. Res. 2019, 110,1-8. [CrossRef]

5. Sinha, A.; Shariq, A.; Said, K.; Sharma, A.; Jeffrey Newport, D.; Salloum, I.M. Medical Comorbidities in Bipolar Disorder. Curr. Psychiatry Rep. 2018, 20, 36. [CrossRef] [PubMed]

6. Judd, L.L.; Akiskal, H.S.; Schettler, P.J.; Endicott, J.; Maser, J.; Solomon, D.A.; Leon, A.C.; Rice, J.A.; Keller, M.B. The long-term natural history of the weekly symptomatic status of bipolar I disorder. Arch. Gen. Psychiatry 2002, 59, 530-537. [CrossRef] [PubMed]

7. Chen, M.; Fitzgerald, H.M.; Madera, J.J.; Tohen, M. Functional outcome assessment in bipolar disorder: A systematic literature review. Bipolar Disord. 2019, 21, 194-214. [CrossRef] [PubMed]

8. Amerio, A.; Odone, A.; Tonna, M.; Stubbs, B.; Ghaemi, S.N. Bipolar disorder and its comorbidities between Feinstein and the Diagnostic and Statistical Manual of Mental Disorders. Aust. N. Z. J. Psychiatry 2015, 49, 1073. [CrossRef] [PubMed]

9. Di Florio, A.; Craddock, N.; van den Bree, M. Alcohol misuse in bipolar disorder. A systematic review and meta-analysis of comorbidity rates. Eur. Psychiatry 2014, 29, 117-124. [CrossRef] [PubMed]

10. Hunt, G.E.; Malhi, G.S.; Cleary, M.; Lai, H.M.X.; Sitharthan, T. Prevalence of comorbid bipolar and substance use disorders in clinical settings, 1990-2015: Systematic review and meta-analysis. J. Affect. Disord. 2016, 206, 331-349. [CrossRef] [PubMed]

11. Hunt, G.E.; Malhi, G.S.; Cleary, M.; Lai, H.M.X.; Sitharthan, T. Comorbidity of bipolar and substance use disorders in national surveys of general populations, 1990-2015: Systematic review and meta-analysis. J. Affect. Disord. 2016, 206, 321-330. [CrossRef] [PubMed]

12. Nabavi, B.; Mitchell, A.J.; Nutt, D. A Lifetime Prevalence of Comorbidity Between Bipolar Affective Disorder and Anxiety Disorders: A Meta-analysis of 52 Interview-based Studies of Psychiatric Population. EBioMedicine 2015, 2, 1405-1419. [CrossRef] [PubMed]

13. Pavlova, B.; Perlis, R.H.; Mantere, O.; Sellgren, C.M.; Isometsä, E.; Mitchell, P.B.; Alda, M.; Uher, R. Prevalence of current anxiety disorders in people with bipolar disorder during euthymia: A meta-analysis. Psychol. Med. 2017, 47, 1107-1115. [CrossRef] [PubMed]

14. Forty, L.; Ulanova, A.; Jones, L.; Jones, I.; Gordon-Smith, K.; Fraser, C.; Farmer, A.; McGuffin, P.; Lewis, C.M.; Hosang, G.M.; et al. Comorbid medical illness in bipolar disorder. Br. J. Psychiatry 2014, 205, 465-472. [CrossRef] [PubMed]

15. McElroy, S.L.; Altshuler, L.L.; Suppes, T.; Keck, P.E.; Frye, M.A.; Denicoff, K.D.; Nolen, W.A.; Kupka, R.W.; Leverich, G.S.; Rochussen, J.R.; et al. Axis I psychiatric comorbidity and its relationship to historical illness variables in 288 patients with bipolar disorder. Am. J. Psychiatry 2001, 158, 420-426. [CrossRef] [PubMed]

16. Preti, A.; Vrublevska, J.; Veroniki, A.A.; Huedo-Medina, T.B.; Kyriazis, O.; Fountoulakis, K.N. Prevalence and treatment of panic disorder in bipolar disorder: Systematic review and meta-analysis. Evid. Based. Ment. Health 2018, 21, 53-60. [CrossRef] [PubMed]

17. Goldstein, R.B.; Compton, W.M.; Grant, B.F. Antisocial Behavioral Syndromes and Additional Psychiatric Comorbidity in Posttraumatic Stress Disorder Among U.S. Adults: Results From Wave 2 of the National Epidemiologic Survey on Alcohol and Related Conditions. J. Am. Psychiatr. Nurses Assoc. 2010, 16, 145-165. [CrossRef]

18. Hossain, S.; Mainali, P.; Bhimanadham, N.N.; Imran, S.; Ahmad, N.; Patel, R.S. Medical and Psychiatric Comorbidities in Bipolar Disorder: Insights from National Inpatient Population-based Study. Cureus 2019, 11, e5636. [CrossRef] [PubMed]

19. Maina, G.; Albert, U.; Pessina, E.; Bogetto, F. Bipolar obsessive-compulsive disorder and personality disorders. Bipolar Disord. 2007, 9, 722-729. [CrossRef] [PubMed]

20. Simon, N.M.; Otto, M.W.; Wisniewski, S.R.; Fossey, M.; Sagduyu, K.; Frank, E.; Sachs, G.S.; Nierenberg, A.A.; Thase, M.E.; Pollack, M.H. Anxiety disorder comorbidity in bipolar disorder patients: Data from the first 500 participants in the Systematic Treatment Enhancement Program for Bipolar Disorder (STEP-BD). Am. J. Psychiatry 2004, 161, 2222-2229. [CrossRef] [PubMed]

21. Thiebaut, S.; Godart, N.; Radon, L.; Courtet, P.; Guillaume, S. Crossed prevalence results between subtypes of eating disorder and bipolar disorder: A systematic review of the literature. Encephale 2019, 45, 60-73. [CrossRef] [PubMed]

22. Pinna, M.; Visioli, C.; Rago, C.M.; Manchia, M.; Tondo, L.; Baldessarini, R.J. Attention deficit-hyperactivity disorder in adult bipolar disorder patients. J. Affect. Disord. 2019, 243, 391-396. [CrossRef] [PubMed]

23. Cerimele, J.M.; Bauer, A.M.; Fortney, J.C.; Bauer, M.S. Patients with co-occurring bipolar disorder and posttraumatic stress disorder: A rapid review of the literature. J. Clin. Psychiatry 2017, 78, e506-e514. [CrossRef] [PubMed]

24. Bezerra-Filho, S.; Almeida, A.G.; Studart, P.; Rocha, M.V.; Lopes, F.L.; Miranda-Scippa, Â. Personality disorders in euthymic bipolar patients: A systematic review. Rev. Bras. Psiquiatr. 2015, 37, 162-167. [CrossRef] [PubMed]

25. Fan, A.H.; Hassell, J. Bipolar disorder and comorbid personality psychopathology: A review of the literature. J. Clin. Psychiatry 2008, 69, 1794-1803. [CrossRef] [PubMed]

26. Harnic, D.; Catalano, V.; Mazza, M.; Janiri, L.; Bria, P. An observational study evaluating comorbidity between bipolar disorder and personality disorders. Clin. Ter. 2010, 161, 51-54. [PubMed]

27. Friborg, O.; Martinsen, E.W.; Martinussen, M.; Kaiser, S.; Øvergård, K.T.; Rosenvinge, J.H. Comorbidity of personality disorders in mood disorders: A meta-analytic review of 122 studies from 1988 to 2010. J. Affect. Disord. 2014, 152-154, 1-11. [CrossRef] [PubMed] 
28. Fowler, J.C.; Madan, A.; Allen, J.G.; Oldham, J.M.; Frueh, B.C. Differentiating bipolar disorder from borderline personality disorder: Diagnostic accuracy of the difficulty in emotion regulation scale and personality inventory for DSM-5. J. Affect. Disord. 2019, 245, 856-860. [CrossRef] [PubMed]

29. Quanbeck, C.D.; Stone, D.C.; Scott, C.L.; McDermott, B.E.; Altshuler, L.L.; Frye, M.A. Clinical and legal correlates of inmates with bipolar disorder at time of criminal arrest. J. Clin. Psychiatry 2004, 65, 198-203. [CrossRef] [PubMed]

30. Yen, S.; Frazier, E.; Hower, H.; Weinstock, L.M.; Topor, D.R.; Hunt, J.; Goldstein, T.R.; Goldstein, B.I.; Gill, M.K.; Ryan, N.D.; et al Borderline personality disorder in transition age youth with bipolar disorder. Acta Psychiatr. Scand. 2015, 132, 270-280. [CrossRef] [PubMed]

31. Post, R.M.; McElroy, S.; Kupka, R.; Suppes, T.; Hellemann, G.; Nolen, W.; Frye, M.; Keck, P.; Grunze, H.; Rowe, M. Axis II personality disorders are linked to an adverse course of bipolar disorder. J. Nerv. Ment. Dis. 2018, 206, 469-472. [CrossRef] [PubMed]

32. Latalova, K.; Prasko, J.; Kamaradova, D.; Sedlackova, J.; Ociskova, M. Comorbidity bipolar disorder and personality disorders. Neuro Endocrinol. Lett. 2013, 34, 1-8.

33. Fazel, S.; Lichtenstein, P.; Grann, M.; Goodwin, G.M.; Långström, N. Bipolar disorder and violent crime: New evidence from population-based longitudinal studies and systematic review. Arch. Gen. Psychiatry 2010, 67, 931-938. [CrossRef] [PubMed]

34. Apfelbaum, S.; Regalado, P.; Herman, L.; Teitelbaum, J.; Gagliesi, P. Comorbidity between Bipolar Disorder and Cluster B Personality Disorders as indicator of affective dysregulation and clinical severity. Actas Esp. Psiquiatr. 2013, 41, 269-278.

35. American Psychiatric Association. Diagnostic and Statistical Manual of Mental Disorders. DSM-5, 5th ed.; American Psychiatric Association: Washington, DC, USA, 2013.

36. Samuels, J.; Eaton, W.W.; Bienvenu, O.J.; Brown, C.H.; Costa, P.T.; Nestadt, G. Prevalence and correlates of personality disorders in a community sample. Br. J. Psychiatry 2002, 180, 536-542. [CrossRef] [PubMed]

37. Lenzenweger, M.F. Current status of the scientific study of the personality disorders: An overview of epidemiological, longitudinal, experimental psychopathology, and neurobehavioral perspectives. J. Am. Psychoanal. Assoc. 2010, 58, 741-778. [CrossRef] [PubMed]

38. Etain, B.; Mathieu, F.; Liquet, S.; Raust, A.; Cochet, B.; Richard, J.R.; Gard, S.; Zanouy, L.; Kahn, J.P.; Cohen, R.F.; et al. Clinical features associated with trait-impulsiveness in euthymic bipolar disorder patients. J. Affect. Disord. 2013, 144, 240-247. [CrossRef] [PubMed]

39. Turner, D.; Sebastian, A.; Tüscher, O. Impulsivity and Cluster B Personality Disorders. Curr. Psychiatry Rep. 2017, 19, 15. [CrossRef] [PubMed]

40. Helle, A.C.; Watts, A.L.; Trull, T.J.; Sher, K.J. Alcohol use disorder and antisocial and borderline personality disorders. Alcohol Res. Curr. Rev. 2019, 40, e1-e16. [CrossRef] [PubMed]

41. González, E.; Arias, F.; Szerman, N.; Vega, P.; Mesias, B.; Basurte, I. Coexistence between personality disorders and substance use disorder. Madrid study about prevalence of dual pathology. Actas Esp. Psiquiatr. 2019, 47, 218-228.

42. Messer, T.; Lammers, G.; Müller-Siecheneder, F.; Schmidt, R.F.; Latifi, S. Substance abuse in patients with bipolar disorder: A systematic review and meta-analysis. Psychiatry Res. 2017, 253, 338-350. [CrossRef]

43. Fovet, T.; Geoffroy, P.A.; Vaiva, G.; Adins, C.; Thomas, P.; Amad, A. Individuals with bipolar disorder and their relationship with the criminal justice system: A critical review. Psychiatr. Serv. 2015, 66, 348-353. [CrossRef] [PubMed]

44. Spaans, M.; Barendregt, M.; Haan, B.; Nijman, H.; de Beurs, E. Diagnosis of antisocial personality disorder and criminal responsibility. Int. J. Law Psychiatry 2011, 34, 374-378. [CrossRef] [PubMed]

45. Icick, R.; Melle, I.; Etain, B.; Ringen, P.A.; Aminoff, S.R.; Leboyer, M.; Aas, M.; Henry, C.; Bjella, T.D.; Andreassen, O.A.; et al. Tobacco smoking and other substance use disorders associated with recurrent suicide attempts in bipolar disorder. J. Affect. Disord. 2019, 256, 348-357. [CrossRef] [PubMed]

46. Links, P.S.; Gould, B.; Ratnayake, R. Assessing suicidal youth with antisocial, borderline, or narcissistic personality disorder. Can. J. Psychiatry 2003, 48, 301-310. [CrossRef] [PubMed]

47. Swann, A.C.; Lijffijt, M.; Lane, S.D.; Steinberg, J.L.; Moeller, F.G. Interactions between bipolar disorder and antisocial personality disorder in trait impulsivity and severity of illness. Acta Psychiatr. Scand. 2010, 121, 453-461. [CrossRef] [PubMed]

48. Mitchell, J.D.; Brown, E.S.; Rush, A.J. Comorbid disorders in patients with bipolar disorder and concomitant substance dependence. J. Affect. Disord. 2007, 102, 281-287. [CrossRef]

49. Lev-Ran, S.; Le Foll, B.; McKenzie, K.; George, T.P.; Rehm, J. Bipolar disorder and co-occurring cannabis use disorders: Characteristics, co-morbidities and clinical correlates. Psychiatry Res. 2013, 209, 459-465. [CrossRef] [PubMed]

50. Glenn, A.L.; Johnson, A.K.; Raine, A. Antisocial Personality Disorder: A Current Review. Curr. Psychiatry Rep. 2013, 15, 427. [CrossRef] [PubMed]

51. Fridell, M.; Hesse, M.; Jæger, M.M.; Kühlhorn, E. Antisocial personality disorder as a predictor of criminal behaviour in a longitudinal study of a cohort of abusers of several classes of drugs: Relation to type of substance and type of crime. Addict. Behav. 2008, 33, 799-811. [CrossRef] [PubMed]

52. Swann, A.C. Antisocial personality and bipolar disorder: Interactions in impulsivity and course of illness. Neuropsychiatry (London) 2011, 1, 599-610. [CrossRef] 
53. Liberati, A.; Altman, D.G.; Tetzlaff, J.; Mulrow, C.; Gøtzsche, P.C.; Ioannidis, J.P.A.; Clarke, M.; Devereaux, P.J.; Kleijnen, J.; Moher, D. The PRISMA statement for reporting systematic reviews and meta-analyses of studies that evaluate healthcare interventions: Explanation and elaboration. Br. Med. J. 2009, 339, b2700. [CrossRef]

54. Pluye, P.; Gagnon, M.P.; Griffiths, F.; Johnson-Lafleur, J. A scoring system for appraising mixed methods research, and concomitantly appraising qualitative, quantitative and mixed methods primary studies in Mixed Studies Reviews. Int. J. Nurs. Stud. 2009, 46, 529-546. [CrossRef]

55. Hong, Q.N.; Fàbregues, S.; Bartlett, G.; Boardman, F.; Cargo, M.; Dagenais, P.; Gagnon, M.P.; Griffiths, F.; Nicolau, B.; O'Cathain, A.; et al. The Mixed Methods Appraisal Tool (MMAT) version 2018 for information professionals and researchers. Educ. Inf. 2018, 34, 285-291. [CrossRef]

56. Turley, B.; Bates, G.W.; Edwards, J.; Jackson, H.J. MCMI-II personality disorders in recent-onset bipolar disorders. J. Clin. Psychol. 1992, 48, 320-329. [CrossRef]

57. Goldstein, R.B.; Chou, S.P.; Saha, T.D.; Smith, S.M.; Jung, J.; Zhang, H.; Pickering, R.P.; Ruan, W.J.; Huang, B.; Grant, B.F. The Epidemiology of Antisocial Behavioral Syndromes in Adulthood. J. Clin. Psychiatry 2017, 78, 90-98. [CrossRef] [PubMed]

58. Swann, A.C.; Lijffijt, M.; Lane, S.D.; Steinberg, J.L.; Moeller, F.G. Antisocial personality disorder and borderline symptoms are differentially related to impulsivity and course of illness in bipolar disorder. J. Affect. Disord. 2013, 148, 384-390. [CrossRef] [PubMed]

59. Mueser, K.T.; Gottlieb, J.D.; Cather, C.; Glynn, S.M.; Zarate, R.; Smith, M.F.; Clark, R.E.; Wolfe, R. Antisocial personality disorder in people with co-occurring severe mental illness and substance use disorders: Clinical, functional, and family relationship correlates. Psychosis 2012, 4, 52-62. [CrossRef] [PubMed]

60. Garno, J.L.; Gunawardane, N.; Goldberg, J.F. Predictors of trait aggression in bipolar disorder. Bipolar Disord. 2008, 10, 285-292. [CrossRef] [PubMed]

61. Swann, A.C.; Lijffijt, M.; Lane, S.D.; Steinberg, J.L.; Moeller, F.G. Interacting mechanisms of impulsivity in bipolar disorder and antisocial personality disorder. J. Psychiatr. Res. 2011, 45, 1477-1482. [CrossRef] [PubMed]

62. Perugi, G.; Toni, C.; Maremmani, I.; Tusini, G.; Ramacciotti, S.; Madia, A.; Fornaro, M.; Akiskal, H.S. The influence of affective temperaments and psychopathological traits on the definition of bipolar disorder subtypes: A study on Bipolar I Italian National sample. J. Affect. Disord. 2012, 136, e41-e49. [CrossRef] [PubMed]

63. Garno, J.L.; Goldberg, J.F.; Ramirez, P.M.; Ritzler, B.A. Bipolar disorder with comorbid cluster B personality disorder features: Impact on suicidality. J. Clin. Psychiatry 2005, 66, 339-345. [CrossRef] [PubMed]

64. Mueser, K.T.; Crocker, A.G.; Frisman, L.B.; Drake, R.E.; Covell, N.H.; Essock, S.M. Conduct disorder and antisocial personality disorder in persons with severe psychiatric and substance use disorders. Schizophr. Bull. 2006, 32, 626-636. [CrossRef] [PubMed]

65. Mueser, K.T.; Rosenberg, S.D.; Drake, R.E.; Miles, K.M.; Wolford, G.; Vidaver, R.; Carrieri, K. Conduct disorder, antisocial personality disorder and substance use disorders in schizophrenia and major affective disorders. J. Stud. Alcohol. 1999, 60, 278-284. [CrossRef] [PubMed]

66. Jackson, H.J.; Pica, S. An investigation into the internal structure of DSM-III antisocial personality disorder. Psychol. Rep. 1993, 72, 355-367. [CrossRef] [PubMed]

67. Pica, S.; Edwards, J.; Jackson, H.J.; Bell, R.C.; Bates, G.W.; Rudd, R.P. Personality disorders in recent-onset bipolar disorder. Compr. Psychiatry 1990, 31, 499-510. [CrossRef]

68. Mantere, O.; Melartin, T.K.; Suominen, K.; Rytsälä, H.J.; Valtonen, H.M.; Arvilommi, P.; Leppämäki, S.; Isometsä, E.T. Differences in Axis I and II comorbidity between bipolar I and II disorders and major depressive disorder. J. Clin. Psychiatry 2006, 67, 584-593. [CrossRef] [PubMed]

69. Berk, M.; Dodd, S. Bipolar II disorder: A review. Bipolar Disord. 2005, 7, 11-21. [CrossRef]

70. Ravizza, L.; Barzega, G.; Bellino, S.; Bogetto, F.; Maina, G. Predictors of drug treatment response in obsessive-compulsive disorder. J. Clin. Psychiatry 1995, 56, 368-373. [PubMed]

71. Crawford, T.N.; Cohen, P.; First, M.B.; Skodol, A.E.; Johnson, J.G.; Kasen, S. Comorbid Axis I and Axis II disorders in early adolescence: Outcomes 20 years later. Arch. Gen. Psychiatry 2008, 65, 641-648. [CrossRef] [PubMed]

72. Post, R.M.; Leverich, G.S.; McElroy, S.; Kupka, R.; Suppes, T.; Altshuler, L.; Nolen, W.; Frye, M.; Keck, P.; Grunze, H.; et al. Prevalence of axis II comorbidities in bipolar disorder: Relationship to mood state. Bipolar Disord. 2018, 20, 303-312. [CrossRef] [PubMed]

73. Dunayevich, E.; Sax, K.W.; Keck, P.E.; McElroy, S.L.; Sorter, M.T.; McConville, B.J.; Strakowski, S.M. Twelve-month outcome in bipolar patients with and without personality disorders. J. Clin. Psychiatry 2000, 61, 134-139. [CrossRef] [PubMed]

74. Leverich, G.S.; Altshuler, L.L.; Frye, M.A.; Suppes, T.; Keck, P.E.; McElroy, S.L.; Denicoff, K.D.; Obrocea, G.; Nolen, W.A.; Kupka, R.; et al. Factors associated with suicide attempts in 648 patients with bipolar disorder in the Stanley Foundation Bipolar Network. J. Clin. Psychiatry 2003, 64, 506-515. [CrossRef] [PubMed]

75. Kay, J.H.; Altshuler, L.L.; Ventura, J.; Mintz, J. Impact of axis II comorbidity on the course of bipolar illness in men: A retrospective chart review. Bipolar Disord. 2002, 4, 237-242. [CrossRef] [PubMed]

76. Lembke, A.; Miklowitz, D.J.; Otto, M.W.; Zhang, H.; Wisniewski, S.R.; Sachs, G.S.; Thase, M.E.; Ketter, T.A.; STEP-BD Investigators. Psychosocial service utilization by patients with bipolar disorders: Data from the first 500 participants in the Systematic Treatment Enhancement Program. J. Psychiatr. Pract. 2004, 10, 81-87. [CrossRef] 
77. Jylhä, P.; Rosenström, T.; Mantere, O.; Suominen, K.; Melartin, T.; Vuorilehto, M.; Holma, M.; Riihimäki, K.; Oquendo, M.A.; Keltikangas-Järvinen, L.; et al. Personality disorders and suicide attempts in unipolar and bipolar mood disorders. J. Affect. Disord. 2016, 190, 632-639. [CrossRef] [PubMed]

78. Johansson, P.; Kerr, M.; Andershed, H. Linking adult psychopathy with childhood hyperactivity-impulsivity-attention problems and conduct problems through retrospective self-reports. J. Pers. Disord. 2005, 19, 94-101. [CrossRef] [PubMed]

79. Black, D.W. The natural history of antisocial personality disorder. Can. J. Psychiatry 2015, 60, 309-314. [CrossRef] [PubMed]

80. Connor, D.F.; Ford, J.D.; Pearson, G.S.; Scranton, V.L.; Dusad, A. Early-Onset Bipolar Disorder: Characteristics and Outcomes in the Clinic. J. Child Adolesc. Psychopharmacol. 2017, 27, 875-883. [CrossRef]

81. Croarkin, P.E.; Luby, J.L.; Cercy, K.; Geske, J.R.; Veldic, M.; Simonson, M.; Joshi, P.T.; Wagner, K.D.; Walkup, J.T.; Nassan, M.M.; et al. Genetic risk score analysis in early-onset bipolar disorder. J. Clin. Psychiatry 2017, 78, 1337-1343. [CrossRef] [PubMed]

82. Ferguson, C.J. Genetic contributions to antisocial personality and behavior: A meta-analytic review from an evolutionary perspective. J. Soc. Psychol. 2010, 150, 160-180. [CrossRef] [PubMed]

83. Shi, Z.; Bureau, J.F.; Easterbrooks, M.A.; Zhao, X.; Lyons-Ruth, K. Childhood maltreatment and prospectively observed quality of early care as predictors of antisocial personality disorder features. Infant Ment. Health J. 2012, 33, 55-69. [CrossRef]

84. Agnew-Blais, J.; Danese, A. Childhood maltreatment and unfavourable clinical outcomes in bipolar disorder: A systematic review and meta-analysis. Lancet Psychiatry 2016, 3, 342-349. [CrossRef]

85. Sparding, T.; Pålsson, E.; Joas, E.; Hansen, S.; Landén, M. Personality traits in bipolar disorder and influence on outcome. BMC Psychiatry 2017, 17, 159. [CrossRef] [PubMed]

86. Fulwiler, C.; Grossman, H.; Forbes, C.; Ruthazer, R. Early-onset substance abuse and community violence by outpatients with chronic mental illness. Psychiatr. Serv. 1997, 48, 1181-1185. [PubMed] 